\title{
Postgraduate education: MITs in Britain?
}

ON the same day that the Science Research Council (SRC) was launching its annual report (bearing, predictably, little good news for the practitioners of 'big science') it was also publishing a much less predictable document that makes some very radical suggestions. Postgraduate Training (SRC, free) should be read by every postgraduate, every academic and every industrialist in the business of hiring universityeducated people.

A year and a half ago, the Commons Expenditure Committee looked at the postgraduate training scene in Britain across a spectrum from student funding to national relevance. It took advice from a strangely limited range of witnesses and came up with a dim view of the utility of higher degrees. The Department of Education and Science has been slow to reply to the criticism; in a sense this report can be seen as an attempt to remedy that deficiency. In no way, however, is it a stonewall defence of the status quo. The SRC working party, chaired by Sir Sam Edwards, has instead taken upon itself to inject ideas for change into the debate, and to propose major reorganisation at the postgraduate level.

The guiding principle behind the report is that postgraduate education should become less of a training ground for research workers and more of a broad continuation of the educational process. Several reasons are advanced. One is that the working party sees many scientific disciplines as having established a broad enough base to support technology "for a considerable time", and so there is now a greater need to train for careers for outside research. This point will cause alarm to some who will see it as the thin end of the wedge by which research, particularly in the physical sciences, is to be gently downgraded. Another reason for changing the emphasis of postgraduate training is to help persuade industry to take high qualifications more seriously. The working party has some hard words for the 'watching old Tom' school in which the sooner bright young students are out of university and learning the job by personal experience the better. A third reason, implicit in much that the working party proposes, is that there is a totally unsatisfactory and wasteful relationship between universities and professional bodies. It is farcical that in 1975 the working party has to suggest that the SRC enquire of these bodies whether certain university and polytechnic courses might be approved for professional training schemes. Fourth, even those who are ultimately to stay in research need education far beyond a first degree if they are not to become narrowly specialised. The provision of such education is at present patchy; many PhD students are able to avoid, or are unable to obtain, any formal training from the day they graduate.
The main recommendations are blunt.

- New, broader degrees to be available, both at master's and doctoral level, in which taught courses have an enhanced significance.

- A higher proportion of compulsory course work to be included in the first year of PhD courses.

- The option of proceeding to a $\mathrm{PhD}$ to be open only to those who have taken course work and in addition show aptitude for research.

- Consortia of universities, polytechnics and non-academic bodies to be formed to develop wider ranging courses.

If this looks much closer to the American pattern of postgraduate education, this is by design. The Edwards report is a curious echo of the Flowers report on university computer needs exactly 10 years ago. Then it was IBM which was the object of much admiration; now it is MIT. "We are anxious", says the report, "that the opportunities for graduate instruction offered by MIT should be matched by consortia of British universities, if not by individual universities.",

And then finally, lest any academic applecarts be left un-upset, the working party recommend that postgraduates be paid differentially on the basis of the extent to which their work is of economic importance or in the national interest. Since the giving of grants is basically an SRC concern, such a measure could be rapidly implemented, although it is obvious that it could not be applied fairly except in some rather limited but clearly defined instances particularly favoured by SRC, such as joint SRC/SSRC studentships, total technology studentships and the Co-operative Awards in Science and Engineering (CASE) scheme.

The overall impression left by the report is certainly exciting and progressive, and it will speak directly to all those who know and approve of American higher education. But it all reads a little like a lecture, albeit a very good one, prepared by half-a-dozen lively minds gathered round a dinner table. Can the ideas be carried further than oratory? Is there any evidence, for instance, that the disappointing response to the CASE scheme would not be repeated on a much larger scale? Is there any indication that industry is prepared to accept more highly trained entrants? Do people say bad things about MIT's postgraduate education? Is a broad postgraduate training any use without broader undergraduate training than we have now?

That the working party is serious about its proposals, however, is in no doubt. "At a time when we are having to urge belt-tightening on everyone", says Sir Sam, "we wouldn't be proposing something as expensive as this were we not in deadly earnest". 